\title{
Bank Capital Shocks and Portfolio Risk: Evidence from Japan
}

\author{
Kentaro Iwatsubo*† \\ Hitotsubashi University
}

September 5, 2005

\begin{abstract}
Despite the downward trend of land prices and the ex-post low return on real estate loans, Japanese banks increased their lending to the real estate sector during the 1990s. We argue that this phenomenon can be explained by the risk-shifting incentives of banks and discover that banks with low capital-to-asset ratios and low franchise value chose high-risk assets such as real estate loans. Unlike previous studies, we show that the capital-risk relationship is nonlinear and changes from positive to negative as franchise value falls. We also find that a capital adequacy requirement did not prevent risk-taking behavior of undercapitalized banks since they then just issued more subordinated debts to meet this requirement. In contrast, government capital injections led banks to reduce risky loans at the margin. Recapitalization by issuing subordinated debts helped banks recover their capital losses and mitigated the credit crunch, but consequently allowed them to increase their exposure to the real estate sector and worsened the bad loan problems.
\end{abstract}

*JEL classification: G21, C33. Keywords: Bank risk, Risk-shifting incentives, Franchise value, Capital adequacy requirement.

${ }^{\dagger}$ Contact Address: Kentaro Iwatsubo, Institute of Economic Research, Hitotsubashi University. 2-1 Naka Kunitachi, Tokyo, 186-8603 Japan. Email: iwatsubo@ier.hit-u.ac.jp. Tel \& fax: +81-42-580-8348. 


\section{Introduction}

It is well known that excessive bank lending to the real estate sector was one of the main causes of the Japanese land market boom in the late 1980s. While land prices declined steadily in the 1990s, surprisingly, Japanese banks increased their lending to the real estate sector until 1998. During the same period, total loans outstanding leveled off and loans to some industries, such as manufacturing, declined substantially. Why did banks shift their loan portfolio toward the real estate sector despite the ex-post low return on real estate loans?

The banking literature has long examined risk-taking behavior of banks and most observers agree that moral hazard plays an important role. They describe the problem of "gambling for resurrection": poorly capitalized banks choose a risky asset portfolio at the cost of the deposit insurance system. This risk-shifting incentive, together with the contagion effects of bank failures, has been the main justification of a capital adequacy requirement. However, the relationship between bank capital and risk under a capital adequacy requirement remains, to date, inconclusive. In the theory literature, Koehn and Santomero (1980) and Kim and Santomero (1988), using a mean-variance framework, show that increased regulatory capital standards may lead banks to choose risky portfolios to cover the loss in utility from the decrease in leverage. Conversely, Furlong and Keeley (1989) and Keeley and Furlong (1990) argue, using a contingent-claim model, that an increase in capital reduces the value of the deposit insurance put option, thereby reducing the incentive of banks to increase portfolio risk. The empirical evidence on the effectiveness of capital adequacy requirements is also mixed. ${ }^{1}$

The purpose of this paper is two-fold. At the theory level, we argue that the relationship between capital and risk is nonlinear and varies with respect to franchise value. ${ }^{2}$ At the empirical level, we convincingly document the

\footnotetext{
${ }^{1}$ A number of empirical studies have been undertaken in the U.S. Haubrich and Wachtel (1993) suggest that implementation of the Basel risk-based capital standards caused poorly capitalized banks to reconfigure their portfolios away from high-risk assets toward lowrisk assets. In contrast, Hancock and Wilcox (1994) find that banks which had less capital than required by the risk-based standards shifted their portfolios toward highrisk assets. Shrieves and Dahl (1992) use a simultaneous equation model and find a positive relationship between changes in capital and risk between 1983-1987. Using the same simultaneous equation model, however, Jacques and Nigro (1997) find a negative relation between the two variables during 1990-1991.

${ }^{2}$ The franchise value is defined as the present discounted value of the future stream of rents that banks will be able to obtain (Keeley, 1990).
} 
existence of such a relationship and show that banks with low capital-toasset ratios and low franchise value increased their issuing of real estate loans. We also examine the effects of a capital adequacy requirement and government capital injections on the risk-taking behavior of banks.

In the two-period model we present, bank risk is determined by the tradeoff between a deposit insurance subsidy and future rent or franchise value. An exogenous decline in capital lowers the franchise value, but whether this leads banks to increase or decrease the risk profile of their loans depends on the initial franchise value. If it is sufficiently high, the optimal choice is to lower the amount of risky loans to prevent insolvency, while the riskiness of loans increases if the franchise value is sufficiently low.

In the same framework, we then analyze whether a capital adequacy requirement and capital injections by the government reduce the amount of risk banks take on. We show that a prospective capital requirement leads banks to increase current risk because capital is more expensive in the future binding period so that banks have an incentive to take on risk to increase capital in the current period. Conversely, prospective capital injections by the government allow banks to increase franchise value, and hence, reduce risk in the current period. Our model clearly demonstrates the forwardlooking features of banks' risk-taking behavior which had been overlooked in the banking literature until recently.

The empirical controversy is partly due to the difficulty of finding appropriate measures of bank risk and the regulatory pressure on bank capital. We propose using the real estate loan ratio as a new proxy for the portfolio risk of Japanese banks in the 1990s. The bursting of a real estate market bubble in the early 1990s increased the uncertainty about the expected returns to the real estate investments. We also suggest using the subordinated debt ratio as a proxy for regulatory pressure in the form of a bank capital requirement since Japanese banks with low capital issued more subordinated debts to meet the requirement. ${ }^{3}$ Due to the fact that banks usually avoid operating at the maximum leverage allowed, researchers have used ad-hoc measures for the impact of a capital adequacy requirement. Our proxy enables us to identify the extent of regulatory pressure independent of the

\footnotetext{
${ }^{3}$ A growing number of observers have proposed to use subordinated debt to increase market discipline on banks, which could mitigate moral hazard. Subordinated debt is junior to all claims other than equity, and thus, may deter risk-taking because a bank's expected cost of issuing subordinated debt increases with an increase in the bank's risk portfolio. However, recently Levonian (2001) and Blum (2002) show the ambiguous effect of subordinated debt on risk-taking. The empirical effect of subordinated debt serving as market discipline remains inconclusive.
} 
capital level.

Moreover, simultaneous determination of bank capital and risk complicates efforts to isolate the effect of banks' capital on their risk decisions. The potential problem of endogeneity of bank capital is further complicated by serial correlation of risk. To deal with this, we estimate the dynamic panel model with a generalized method of moments (GMM) estimator based on Arellano and Bond (1991).

Panel data from Japanese banks support our theory. We show evidence that banks with low capital and low franchise value choose high-risk assets and that the slope of risk with respect to capital is negative when the franchise value is low, but becomes positive when franchise value increases sufficiently. This latter observation suggests that banks' franchise value is germane to determining their responses to capital changes. Regarding the effectiveness of regulatory measures, we find that capital-constrained banks took greater risks. Since it was less difficult for these undercapitalized banks to recapitalize by issuing subordinated debts, they did this to meet the capital requirement without a substantial reduction of their assets. However, issuing subordinated debts allowed them to lend more to the real estate sector. In contrast, government capital injections led banks to reduce risky loans at the margin.

The remainder of this paper is organized as follows. Section 2 describes risk and capital positions of Japanese banks in the 1990s, with an emphasis on our measures for bank portfolio risk and regulatory pressure on bank capital. Section 3 illustrates the model used to derive testable hypotheses, while Section 4 shows the empirical methodology and results. Section 5 concludes the paper.

\section{Background}

\subsection{Portfolio Risk}

Figure 1 displays the total loans outstanding and real estate loans outstanding held by all Japanese banks for 1980 to 2000. From 1980 to 1990, both total loans and real estate loans increased substantially. While total loans leveled off in the 1990s, real estate loans continued to increase until 1998. Figure 2 reveals that banks shifted their loan portfolios towards the real estate sector in the 1990s. The share of real estate loans in total loans steadily increased until 1998, while that of manufacturing loans declined substantially. The increase in real estate lending is particularly puzzling, given the downward trend in land prices. As shown in Figure 3, the land 
price index reached a peak in 1991, one year following the peak in stock prices, and then fell continuously until the early 2000s.

In Japan, many bank failures resulted from excessive real estate lending. For example, Nippon Credit bank, for which real estate loans comprised up to 25 percent of total loans, failed in 1998. When two regional banks, Kyoto Kyoei Bank and Naniwa Bank were merged with other banks in 1998, about 30 percent of the total loans held by each bank were real estate loans.

The role real estate loans have played in causing non-performing loan problems in Japan has been widely discussed. Ueda (2000) presents the high correlation between the non-performing loan ratio of 147 banks in 1996 and their share of loans to real estate related industries (real estate, construction, and non-bank financial institutions) in 1990. Hoshi (2001) finds that banks which shifted their loan portfolio more towards the real estate sector between 1983 and 1990 had accumulated larger amounts of non-performing loans by 1998.

Table 1 shows an average of the proportion of non-performing loans by industry for four major city banks in Japan between March 1999 and March 2002 (end of fiscal year). The decomposition of non-performing loans by industry is not available for many banks, as only a few banks had started to disclose such information in their financial reports as of March 1999. The real estate industry has the largest concentration of non-performing loans among the seven industrial categories in the table, climbing to roughly 3035 percent. In contrast, the proportion of non-performing loans from the manufacturing sector is low between 1999 and 2002. Given that real estate loans comprise a lower share of total loans outstanding than manufacturing loans, the real estate loans can be regarded as relatively risky.

In order to be able to take advantage of real estate loan issuance as a proxy for the portfolio risk of banks, we also need to show that their ex-ante risk is high. Indeed, many articles document that investment in the real estate sector, especially commercial real estate development such as office building, retail centers, and industrial facilities, has traditionally been quite risky (Federal Deposit Insurance Corporation, 1997). The riskiness of real estate projects has a number of reasons.

Firstly, real estate construction projects typically have a long gestation period. When completed projects finally come to market, demand conditions may have changed considerably from what they were at the time of conception.

Another cause of risk is that commercial real estate projects tend to be highly leveraged. Real estate developers usually operate with a minimum of capital in order to shift as much of the risk as possible to the lender. Banks 
generally try to protect themselves by requiring low loan-to-value ratios, guarantees, takeout commitments for longer-term financing, and strict loan covenants that will protect them against risky behavior by the developer after the loan is made. But when real estate markets become overheated, underwriting standards often deteriorate.

Boom and bust cycles in the real estate market and banking crises are correlated in a remarkable number of instances in both advanced industrial countries and emerging economies. Norway, Finland and Sweden had similar experiences to Japan in the 1980s and early 1990s. Among emerging economies financial crises of this type have been prevalent since 1980. Examples include Argentina, Chile and most recently the South East Asian countries of Malaysia, Indonesia, Thailand and South Korea.

Kaminsky and Reinhart (1999) study a wide range of crises in 20 countries, including 5 developed countries and 15 emerging ones. A common precursor to most crises considered was financial liberalization and significant credit expansion. These are followed by a substantial rise in the prices of real estate assets and stocks. At some point the bubble bursts and the real estate and stock markets collapse. In many cases, banks and other intermediaries are overexposed to the real estate and equity markets followed by a banking crisis typically a year later.

Although the episodes share the same progression, they also exhibit differences. The most noticeable difference between Japan and other crisis countries is that Japan suffered a banking crisis seven to eight years after the collapse of asset market bubble, a much longer lag than average (Herring and Wachter, 1999). During that period, banks increased their exposure to the real estate sector. It is not certain whether they expected the real estate price decline not to last and land prices to rebound quickly, but in any case the changes in the market indeed increased uncertainty about the expected returns to real estate investments. Japanese banks should have recognized that real estate loans were risky based on the banking crises in other countries.

\subsection{Bank Capital}

The stagnation of asset prices and increased non-performing loans in the 1990s undermined the capital base of the banking industry in Japan. The capital loss occurred at the same time that banks came under increased regulatory pressure. Internationally active banks in Japan were required to achieve the 8 percent capital requirement by March 1993, the end of their fiscal year. 
One distinctive feature for Japanese banks is that they own stocks of both financial and non-financial companies as a part of long-term relationships. Since banks obtained these stocks a long time ago, unrealized capital gains were hidden from the balance sheet in accordance with Japanese accounting standards. Reflecting this fact, 45 percent of unrealized capital gains from long-term holdings are allowed to be counted as tier 2 capital, since they are not intended to be traded for profits. However, as Japanese stock prices fell sharply after the market's peak in December 1989, banks' hidden reserves shrank substantially. In addition, the decline in stock prices made it difficult for banks to issue new equities with attractive terms. Ultimately, banks with low capital ratios were forced to issue subordinated debts and/or reduce lending to meet the capital adequacy requirement.

Figure 4 shows the average capital-to-asset ratio for 35 private banks between 1990 and 2000 which were subject to the 8 percent BIS capital adequacy requirement as of March 1999. The sample includes 9 city banks, 2 long-term credit banks, 6 trust banks and 18 regional banks, representing about 60 percent of total Japanese bank assets in 1999. ${ }^{4}$ The choice of these banks is based on the fact that domestically active banks and internationally active banks seem to have different targets for their capital-to-asset ratio. The capital-to-asset ratio declined until 1992, but increased to 11.5 percent in 2000. The rise in 1999 and 2000 is due to capital injections provided by the government in 1998 and 1999. In response to the significant shortfalls of capital of many banks, the government consequently injected 1.8 million yen (0.4 percent of GDP) in March 1998 and 7.5 million yen (1.6 percent of GDP) in March 1999 into these banks in the form of preferred shares and subordinated debts. ${ }^{5}$

Figure 4 also displays four components of the capital-to-asset ratio. The equity capital ratio had been stable until 1998, while the hidden capital gains declined markedly due to falloffs in stock prices. A substantial reduction in the capital-to-asset ratio was offset mainly by issuing subordinated debts.

As of 1990, the Ministry of Finance has allowed banks to issue subordinated debt in order to help them raise their capital ratios. BIS rules permit up to 50 percent of non-perpetual subordinated debt with a maturity of

\footnotetext{
${ }^{4}$ The sample includes those regional banks which do not have international operations but which elected to be subject to the 8 percent BIS capital adequacy requirement.

${ }^{5}$ To qualify for the capital injection, banks were required to submit a restructuring plan (including the raising of new capital from the private sector) which would be subject to review on a quarterly basis. If the progress in the restructuring of a bank was not satisfactory, its holdings of preferred stocks would be converted to common stocks after a certain grace period, a policy intended to put pressure on management.
} 
longer than five years to be counted as tier 2 capital. Furthermore, 100 percent of perpetual subordinated debt with a maturity of longer than five years is also allowed to be counted as tier 2 capital. Subordinated debt played an important role in the process of recapitalization of Japanese banks. Without issuing subordinated debts, the capital-to-asset ratio of the major banks would have declined below 8 percent.

We will examine what has driven banks' decisions to issue subordinated debt. Horiuchi and Shimizu (1998) and Ito and Sasaki (1998) find that banks with low capital reserves issued more subordinated debts. However, they do not take into account the censored character of the subordinated debt data (Horiuchi and Shimizu) or individual heterogeneity (Ito and Sasaki). We estimate a Tobit model with random effects. The equation estimated is

$$
\begin{aligned}
Y_{i, t}= & \alpha+\beta_{1} \text { equity }_{i, t-1}+\beta_{2} \text { hidden }_{i, t-1}+\beta_{3} \text { provision }_{i, t-1} \\
& +\sum_{j=1991}^{2000} \beta_{j} j_{-} \text {dum }_{t}+\varepsilon_{i, t} \\
\text { where } \varepsilon_{i, t}= & \mu_{i}+\omega_{i, t}, \quad \mu_{i} \sim N\left(0, \sigma_{\mu}^{2}\right), \quad \omega_{i, t} \sim N\left(0, \sigma_{\omega}^{2}\right) \\
\text { sub }_{i, t}= & Y_{i, t} \quad \text { if } Y_{i, t}>0, \\
= & 0 \quad \text { if } Y_{i, t} \leq 0, \\
\text { and } j_{-} \text {dum }_{t}= & 1 \quad \text { if } j=t, \\
= & 0 \quad \text { if } j \neq t .
\end{aligned}
$$

The latent variable $(Y)$ in the index function equals the ratio of subordinated debts to total risk-adjusted assets $(s u b)$, if it takes a non-negative value. The independent variables in the function are bank equity capital (equity), hidden capital gains (hidden) and provisions for loan losses (provision), each as a proportion of total risk-adjusted assets. To mitigate the potential simultaneity problem, all independent variables, except for year dummies, are taken at time $t-1$. Year dummies $\left(j_{-} d u m\right)$ are included to control for time trends. The sample period is between 1990 and 2000.

Table 2 shows the results of the Tobit model and the random-effects Tobit model. The results are consistent with previous studies, suggesting that banks with lower equity capital, lower hidden capital gains, and lower provisions for loan losses issued more subordinated debt. Since banks were allowed to issue subordinated debt in 1990, they have compensated for the shortfalls of equity capital and hidden capital gains by issuing subordinated debt to meet the capital adequacy requirement. Although the capital requirement was seemingly unbinding for all banks, it was a severe hurdle especially for undercapitalized banks. Since it was difficult to quickly recapitalize in the face of large amounts of non-performing loans and a stagnant 
stock market, subordinated debt was the only instrument to help undercapitalized banks sustain their capital bases at relatively high levels. In light of this, we use the subordinated debt ratio as a proxy for the regulatory pressure of a capital adequacy requirement in section 4 .

\section{Theory}

To develop testable hypotheses, we present a model to analyze the effects of three types of shocks to bank capital on risk-taking. These are: (1) a decline in asset values, (2) application of the Basel Accords on Capital Standards and (3) capital injections by the government. Our two-period model allows for three types of bank capital shocks to have different impacts on bank risk; for example, tightening the capital adequacy requirement does not have the same effect as government capital injections.

This model builds on Blum (1999). While Blum (1999) focuses on the effects of a capital requirement on risk, our model aims at analyzing the effects of a capital decline on risk decisions and the effectiveness of policy measures including capital injections by the government.

In this model, bank risk is determined by the trade-off between a deposit insurance subsidy and future rent or franchise value. ${ }^{6}$ While a bank's risktaking increases profits when successful, it also increases the probability of bank failure and, thereby, increases the probability of losing franchise value which shareholders would otherwise enjoy.

Consider the following two-period model. At time $t=0$, a bank invests all of its assets and at time $t=1$ returns are realized. If the bank does not default, another investment can be undertaken. After one period the final returns are realized at $t=2$. We assume that bank managers are risk neutral and maximize the expected value of their equity at $t=2$ in the interest of shareholders.

The bank is financed by equity and deposits. While the initial stock of equity is exogenously given, the bank chooses deposits $D_{0}$ at $t=0$. After one period, the bank has to pay the cost of deposits $C\left(D_{0}\right)$ with $C^{\prime}, C^{\prime \prime}>0$ and $C(0)=0$. This cost function results from an imperfect

\footnotetext{
${ }^{6}$ The model extends the argument of Merton (1977), Marcus (1984) and Keeley (1990). Merton (1977) shows that deposit insurance can be viewed as a put option on the value of the bank's asset. If the insurance premium is risk-insensitive, the bank can increase the value of the put option by increasing the risk of its asset and/or decreasing its capital-toassets ratio. This moral hazard hypothesis is refined by Marcus (1984) and Keeley (1990), who consider that banks have an incentive to take on risk when the bank franchise value falls sufficiently.
} 
competition framework under which horizontally differentiated banks enjoy a local monopoly. If they want to attract more deposits, they have to raise interest rates to increase their market share.

We assume that all depositors are protected by full deposit insurance. Since depositors are perfectly insured, depositors can get their money back no matter how riskily the bank behaves. Therefore the demand for deposits is independent of the bank's riskiness. ${ }^{7}$

At $t=0$ the bank has two investment opportunities: a safe asset with gross rate of return $R_{f} \geq 1$ and a risky portfolio. We assume the following two point distribution of the gross rate of return $\widetilde{R}$ on the risky portfolio.

$$
\begin{aligned}
\widetilde{R} & =X \text { with probability } p(X) \\
& =0 \text { with probability } 1-p(X)
\end{aligned}
$$

for $X \geqslant R_{f}$, with $p\left(R_{f}\right)=1$. We assume that $p^{\prime}(X)<0$, that is, the high rate of return is associated with a low probability of success. Together with $p^{\prime \prime}(X) \leqslant 0$, these assumptions imply that the expected return $E[\widetilde{R} \mid X]=$ $p(X) X$ is strictly concave in $X$. In a certain range the expected return is positively correlated with the level of risk $X$, while after some point a further increase in risk leads to a decrease in expected returns. This return structure is similar to that of Stiglitz and Weiss (1981) and allows us to avoid corner solutions with infinite risk. In order for the expected return to be increasing in $X$ at $R_{f}$, we also assume that $p^{\prime}(X)>-1 / R_{f}$. Hence, the safe asset is weakly dominated by the risky portfolio. Since all the funds are invested in the risky portfolio, the probability of default is $1-p(X)$ for every given $X$. The level of risk $X$ is chosen by the bank at $t=0$.

If the available funds at $t=1$ are not sufficient to cover the costs $C\left(D_{0}\right)$, the bank will default and all the remaining funds are transferred to the deposit insurance funds which also pays depositors their contracted returns. Due to limited liability, bank owners are not forced to pay any additional amount to cover unfulfilled claims.

In period 2 , the model has the same structure as period 1 . While the costs of deposits $D_{1}$ are $C\left(D_{1}\right)$ (with $C^{\prime}, C^{\prime \prime}>0, C(0)=0$ ), the amount of bank equity $W_{1}$ is determined by the initial amount $W_{0}$ plus the profits or losses of period 1. To simplify the model structure, we abstract from

\footnotetext{
${ }^{7}$ In Japan, all banks are obliged to join the deposit insurance system which was introduced in 1971. Japanese deposit insurance covers up to 10 million yen of deposits. The insurance premium imposed on banks is 0.024 percent of the outstanding amount of eligible deposits. Hence, the premium is unrelated to the degree of risk that banks are actually exposed to.
} 
uncertainty in period 2 and replace the random variable in the second period with its expected value $\bar{R}>R_{f}$.

\subsection{Capital Declines and Risk}

First we consider the impact of a decline in bank capital on risk-taking behavior. An unregulated bank solves for expected profits:

$\max _{X, D_{0}, D_{1}} E\left(W_{2}\right)=p(X)\left\{\left(W_{1}+D_{1}\right) \bar{R}-C\left(D_{1}\right)\right\}+(1-p(X)) \max \left\{0,-C\left(D_{0}\right)\right\}$

where $W_{1}=X\left(W_{0}+D_{0}\right)-C\left(D_{0}\right)$ is the value of equity at $t=1$ in case of success. Due to limited liability, the value of equity in case of failure is zero and the bank cannot continue operation. Therefore, the second term is zero. Rewriting this, we get

$$
\max p(X)\left\{\left[X\left(W_{0}+D_{0}\right)-C\left(D_{0}\right)+D_{1}\right] \bar{R}-C\left(D_{1}\right)\right\} .
$$

The first order conditions are

$$
\begin{gathered}
p^{\prime}(\widehat{X})\left[\left(\widehat{W}_{1}+\widehat{D}_{1}\right) \bar{R}-C\left(\widehat{D}_{1}\right)\right]+p(\widehat{X}) \bar{R}\left(W_{0}+\widehat{D}_{0}\right)=0 \\
\text { where } \widehat{W}_{1}=\widehat{X}\left(W_{0}+\widehat{D}_{0}\right)-C\left(\widehat{D}_{0}\right) \\
\widehat{X}=C^{\prime}\left(\widehat{D}_{0}\right) \\
\bar{R}=C^{\prime}\left(\widehat{D}_{1}\right)
\end{gathered}
$$

We will denote the values of $X, D_{0}, D_{1}$ which satisfy these conditions by $\widehat{X}, \widehat{D}_{0}, \widehat{D}_{1}$.

The first term in Eq.(1) represents the marginal cost of increasing risk and the second term is the marginal return on risk. The expression in brackets is the profit of the bank in case of success. Increasing risk slightly lowers the probability of success by $p^{\prime}(X)$, and therefore lowers the expected profits. The second term is the marginal return on risk. A higher risk is associated with a higher return on the total amount of funds invested in the risky asset at $t=0, W_{0}+\widehat{D}_{0}$. This higher return in the case of success in turn translates into a higher amount of equity at $t=1$, which can be invested in the risky asset with return $\bar{R}$. Therefore, an increase in risk by one unit increases the profits, as long as the bank does not default, by $\bar{R}\left(W_{0}+\widehat{D}_{0}\right)$. At the optimal level of risk, marginal cost equals marginal return. 
Now, we want to determine the impact of a decline in bank capital on risk-taking. In order to do this, we totally differentiate Eqs. (1), (2), (3) and apply the implicit function theorem, giving us the following equation:

$$
\frac{d \widehat{X}}{d W_{0}}=-\frac{\left(p^{\prime}(\widehat{X}) \widehat{X}+p(\widehat{X})\right) \bar{R}}{p^{\prime \prime}(\widehat{X})\left\{\bar{R}\left(\widehat{W}_{1}+\widehat{D}_{1}\right)-C\left(\widehat{D}_{1}\right)\right\}+2 p^{\prime}(\widehat{X})\left(W_{0}+\widehat{D}_{0}\right) \bar{R}} .
$$

Inserting Eq.(1) into the numerator of the Eq.(4), we get

$$
\begin{aligned}
\frac{d \widehat{X}}{d W_{0}}= & -\left[p^{\prime}(\widehat{X})\left\{C\left(\widehat{D}_{0}\right) \bar{R}-\left(\widehat{D}_{1} \bar{R}-C\left(\widehat{D}_{1}\right)\right)\right\}\right] \\
& /\left[p^{\prime \prime}(\widehat{X})\left\{\bar{R}\left(\widehat{W}_{1}+\widehat{D}_{1}\right)-C\left(\widehat{D}_{1}\right)\right\}\left(W_{0}+\widehat{D}_{0}\right)+2 p^{\prime}(\widehat{X}) \bar{R}\left(W_{0}+\widehat{D}_{0}\right)^{2}\right] .
\end{aligned}
$$

While the denominator is clearly negative, the sign of the numerator is not obviously determined.

If the expected profit obtained by issuing deposits in period $2, \widehat{D}_{1} \bar{R}-$ $C\left(\widehat{D}_{1}\right)$, is high enough to exceed $C\left(\widehat{D}_{0}\right) \bar{R}$, the numerator becomes negative. This suggests that the bank lowers the risk of its loan portfolio when it loses bank capital at $t=0$. Conversely, if the expected profit obtained by issuing deposits in period 2 is lower than $C\left(\widehat{D}_{0}\right) \bar{R}$, the bank increases its risk in response to a decline in its capital. The reason is that in case of failure, the bank not only has a payoff of zero in period 1 but also loses profits in period 2. If the future profits are sufficiently high, it is optimal for the bank to reduce risk to increase the probability of getting these rents. In contrast, the bank has an incentive to increase risk if the future profits are low.

Proposition 1 Under the flat-rate deposit insurance system, an exogenous decline in capital leads a bank to increase the riskiness of its loan portfolio if its franchise value is sufficiently low. Conversely, if the franchise value is sufficiently high the bank will lower its chosen risk level.

\subsection{Policy Shocks to Bank Capital}

We then consider two kinds of policy shocks to bank capital: applying the Basel Accord on Capital Standards and capital injections by the government. To figure out whether bank risk can be hindered by prospective prudential policies, we assume that these policies are implemented at $t=1$. This implies that the bank decides the level of risk at $t=0$ anticipating that it would be constrained in capital or recapitalized by the government at $t=1 .^{8}$

\footnotetext{
${ }^{8}$ The following facts are consistent with this assumption. The BIS capital adequacy requirement was fully effective in 1993, but the schedule had been known in 1988. Similarly,
} 


\subsubsection{Capital Adequacy Requirements}

We first examine how the level of risk changes today if a bank faces a binding capital constraint in a future period. According to the Basel Accord of 1988, the value of bank capital has to be at least as high as a given fraction of all risk-weighted assets. ${ }^{9}$ In this model a capital-asset ratio $c$ in period 2 implies that a bank can invest no more than $W_{1} / c \equiv k W_{1}$ in the risky portfolio. ${ }^{10}$ If the capital adequacy requirement is binding, as much as possible is invested in the risky asset, $k W_{1}$. For this, $(k-1) W_{1}$ deposits are necessary. Beyond that, the bank can issue further deposits $\bar{D}_{1}$, as long as these funds are invested in the safe asset. The total amount of deposits is therefore

$$
D_{1}=\max \left\{(k-1) W_{1}, C^{\prime-1}\left(R_{f}\right)\right\}
$$

or

$$
D_{1}=(k-1) W_{1}+\bar{D}_{1} .
$$

The problem the bank has to solve is

$$
\max _{X, D_{0}, \bar{D}_{1}} p(X)\left\{k W_{1} \bar{R}+\bar{D}_{1} R_{f}-C\left(D_{1}\right)\right\}, \quad \bar{D}_{1} \geq 0
$$

where $W_{1}=\left(W_{0}+D_{0}\right) X-C\left(D_{0}\right)$ is the value of capital in the case of success.

The first order conditions are:

$$
\begin{gathered}
p^{\prime}\left(X^{r}\right)\left\{k W_{1}^{r} \bar{R}+\bar{D}_{1}^{r} R_{f}-C\left(D_{1}^{r}\right)\right\}+p\left(X^{r}\right)\left(W_{0}+D_{0}^{r}\right)\left\{k \bar{R}-(k-1) C^{\prime}\left(D_{1}^{r}\right)\right\}=0 \\
X^{r}=C^{\prime}\left(D_{0}^{r}\right) \\
R_{f}-C^{\prime}\left(D_{1}^{r}\right) \leq 0, \quad \bar{D}_{1}^{r}\left[R_{f}-C^{\prime}\left(D_{1}^{r}\right)\right]=0, \quad \bar{D}_{1}^{r} \geq 0 .
\end{gathered}
$$

We denote $X, D_{0}, D_{1}, \bar{D}_{1}$ satisfying these conditions by $X^{r}, D_{0}^{r}, D_{1}^{r}, \bar{D}_{1}^{r}$.

To analyze the effect of the capital requirement on the risk-taking behavior of a bank, we totally differentiate Eq. (5) and (6) and apply the implicit

it was widely believed that government did not allow banks to fail until the banking crisis in the late 1990s. Thus, capital injections by the government were not startling when they took place in 1998.

${ }^{9}$ Dewatripont and Tirole (1995) offer a detailed explanation of the Basel Accord on Capital Standards.

${ }^{10}$ It should be noted that, in contrast to most models in the literature, the capital requirements are not necessarily binding in reality. Milne (2002) and Gan (2001) consider this puzzle. 
function theorem to get

$$
\begin{aligned}
& \frac{d X^{r}}{d k}=-\left[p^{\prime}\left(X^{r}\right) W_{1}^{r}\left\{\bar{R}-C^{\prime}\left(D_{1}^{r}\right)\right\}+p\left(X^{r}\right)\left(W_{0}+D_{0}^{r}\right)\left\{\bar{R}-C^{\prime}\left(D_{1}^{r}\right)-H_{1}\right\}\right] \\
& /\left[p^{\prime \prime}\left(X^{r}\right)\left\{k W_{1}^{r} \bar{R}+\bar{D}_{1}^{r} R_{f}-C\left(D_{1}^{r}\right)\right\}+2 p^{\prime}\left(X^{r}\right)\left(W_{0}+D_{0}^{r}\right)\right. \\
& \left.\left\{k \bar{R}-(k-1) C^{\prime}\left(D_{1}^{r}\right)\right\}-p\left(X^{r}\right) H_{2}\right] \\
& \text { where } H_{1}=(k-1) W_{1}^{r} C^{\prime \prime}\left(D_{1}^{r}\right) \text { if } \bar{D}_{1}=0 \text {, } \\
& =0 \quad \text { if } \bar{D}_{1}>0 \text {. } \\
& H_{2}=(k-1)^{2}\left(W_{0}+D_{0}^{r}\right)^{2} C^{\prime \prime}\left(D_{1}^{r}\right) \text { if } \bar{D}_{1}=0, \\
& =0 \quad \text { if } \bar{D}_{1}>0 \text {. }
\end{aligned}
$$

As before, the denominator of Eq.(8) is negative, while the numerator is not obviously of a given sign. Hence, the level of risk may either increase or decrease if the capital requirement is tightened. However, at the point where the capital requirement becomes just binding, we know from Eq.(3) that $\bar{R}=C^{\prime}\left(D_{1}^{r}\right)$. At that point the numerator is $p\left(X^{r}\right)\left(W_{0}+D_{0}^{r}\right) H_{1}$, which must be positive. Hence, the risk unambiguously increases if the requirement is tightened ( $k$ decreases and $c$ increases).

The key insight can be obtained from Eq. (5). As before, the first term represents the marginal cost of increasing risk and the second term the marginal return on risk. Under a binding capital constraint, the profits in case of success become lower; hence, the marginal cost of taking risk is lowered. On the other hand, a binding regulation increases the marginal return of taking risk because the marginal value of equity is higher than in the absence of any regulations. Without capital constraints, an additional unit of equity at $t=1$ is invested in the risky asset and generates an additional return of $\bar{R}$. If a bank faces the binding constraint, an additional unit of equity allows the bank to invest $k$ units in the risky asset and generates a return of $k \bar{R}$. Since $k>1$, the bank has to increases the supply of deposits by $(k-1)$ to finance the difference between the possible investment of size $k$ and the available units of equity. These deposits cost $(k-1) C^{\prime}\left(D_{1}^{r}\right)$. Since $\bar{R} \geq C^{\prime}\left(D_{1}^{r}\right)$ if the requirement is binding, the marginal value of equity at $t=1$ is higher than in the absence of a capital requirement.

$$
k \bar{R}-(k-1) C^{\prime}\left(D_{1}^{r}\right) \geq \bar{R} .
$$

Hence, under binding capital constraints, an additional unit of equity is more valuable for a bank. If raising equity is excessively costly, the only way to increase equity in period 2 is to increase risk in period 1. 
As the requirement is further tightened, risk increases further. Ultimately, the sign of the numerator changes and the risk decreases. ${ }^{11}$ However, the risk cannot be lowered below the unconstrained level of risk, $\widehat{X}$. To understand this, we consider the case of tightest regulation, $k=1$;

$$
p^{\prime}\left(X^{r}\right) X^{r}+p\left(X^{r}\right)-p^{\prime}\left(X^{r}\right)\left[\frac{C\left(D_{0}^{r}\right)}{D_{0}^{r}+W_{0}}-\frac{D_{1}^{r} R_{f}-C\left(D_{1}^{r}\right)}{\bar{R}\left(D_{0}^{r}+W_{0}\right)}\right]=0 .
$$

Rewriting Eq.(1), we get

$$
p^{\prime}(\widehat{X}) \widehat{X}+p(\widehat{X})-p^{\prime}(\widehat{X})\left[\frac{C\left(\widehat{D}_{0}\right)}{\widehat{D}_{0}+W_{0}}-\frac{\widehat{D}_{1} \bar{R}-C\left(\widehat{D}_{1}\right)}{\bar{R}\left(\widehat{D}_{0}+W_{0}\right)}\right]=0 .
$$

Comparing Eq.(9) and (10), it is clear that $X^{r}>\widehat{X}$ since $D_{1}^{r} R_{f}-$ $C\left(D_{1}^{r}\right)<\widehat{D}_{1} \bar{R}-C\left(\widehat{D}_{1}\right)$. It should be noted that even if a bank only expects a future capital requirement to increase, this may lead to an adverse effect on its choice of risk today. In this case, the prospective prudential regulation, aimed at making the banking industry safer in the future, will actually make it more risky in the current period. ${ }^{12}$

Proposition 2 If a bank faces a binding capital adequacy requirement in the future, the level of risk today is higher than in the absence of a capital requirement.

\subsubsection{Government Capital Injections}

This section considers the effect of a capital injection by the government on risk-taking behavior. We assume that the government recapitalizes a bank with $K(>0)$ at $t=1$.

The recapitalized bank's problem is

$$
\max _{X, D_{0}, D_{1}} p(X)\left\{\left(W_{1}+D_{1}+K\right) \bar{R}-C\left(D_{1}\right)\right\}
$$

where $W_{1}=X\left(W_{0}+D_{0}\right)-C\left(D_{0}\right)$ is the value of equity at $t=1$.

The first order conditions are:

$$
p^{\prime}\left(X^{c}\right)\left[\left(W_{1}^{c}+D_{1}^{c}+K\right) \bar{R}-C\left(D_{1}^{c}\right)\right]+p\left(X^{c}\right) \bar{R}\left(W_{0}+D_{0}^{c}\right)=0
$$

\footnotetext{
${ }^{11}$ Using Eq. (9), it is straightforward to show that the denominator of Eq. (8) is positive at $k=1$.

${ }^{12}$ As Blum (1999) discusses, if a bank faces a binding constraint in the first period, it decreases its risk.
} 


$$
\begin{gathered}
\text { where } W_{1}^{c}=X^{c}\left(W_{0}+D_{0}^{c}\right)-C\left(D_{0}^{c}\right) \\
X^{c}=C^{\prime}\left(D_{0}^{c}\right) \\
\bar{R}=C^{\prime}\left(D_{1}^{c}\right) .
\end{gathered}
$$

We denote the values of $X, D_{0}, D_{1}$ which satisfy these conditions by $X^{c}, D_{0}^{c}, D_{1}^{c}$.

Compared with an unregulated bank, the profit of a recapitalized bank in case of success increases by $K$, which increases the marginal cost of taking risk. By contrast, the marginal return on risk remains unchanged. Therefore, the optimal level of risk decreases as the size of the capital injection increases. To solve for the effect of a capital injection by the government, we again totally differentiate Eqs. (11), (12), (13) and apply the implicit function theorem to get

$$
\frac{d X^{c}}{d K}=-\frac{p^{\prime}\left(X^{c}\right) \bar{R}}{p^{\prime \prime}\left(X^{c}\right)\left\{\bar{R}\left(W_{1}^{c}+D_{1}^{c}+K\right)-C\left(D_{1}^{c}\right)\right\}+2 p^{\prime}\left(X^{c}\right)\left(W_{0}+D_{0}^{c}\right) \bar{R}}<0 .
$$

The sign is obviously negative, meaning that the chosen level of risk is lower than in the absence of any regulation and recapitalization. The capital injection by the government at $t=1$ increases the banks' franchise value, which prevents the bank from taking risk at $t=0 .{ }^{13}$

Proposition 3 Prospective government capital injections reduce a bank's risk today.

\section{Empirical Results}

This section tests the implications of the hypotheses developed in the last section with panel data from 35 major banks that are subject to the 8 percent international capital requirement. We use the real estate loan ratio as a proxy for the portfolio risk of Japanese banks in the 1990s.

\subsection{Effect of Capital on Risk}

First we examine whether weakly capitalized banks take greater risks if they have low franchise values and whether they choose lower risk if they have

\footnotetext{
${ }^{13}$ If the government injects capital in the first period, then whether banks increase or decrease the risk depends on the franchise value.
} 
high franchise values (Proposition 1). We estimate the following regression equation:

$$
\begin{gathered}
\operatorname{risk}_{i, t}=\alpha_{1}+\beta_{1} \operatorname{risk}_{i, t-1}+\beta_{2} \operatorname{cap}_{i, t}+\beta_{3} \operatorname{fran}_{i, t}+\beta_{4} \operatorname{cap}_{i, t} \times \operatorname{fran}_{i, t}+B Z_{t}+\varepsilon_{i, t} \\
\varepsilon_{i, t}=\mu_{i}+\nu_{i, t} .
\end{gathered}
$$

The dependent variable (risk) is real estate loans as a share of total loans outstanding. The independent variables include the lagged real estate ratio $\left(\right.$ risk $\left._{-1}\right)$, the ratio of capital to risk-adjusted assets (cap) and franchise value (fran). Following Keeley (1990), we use Tobin's average q, defined as the ratio of total market value to book value of equity capital, as a proxy for franchise value. The interaction term between the capital-to-asset ratio and the franchise value is also included to allow us to analyze the capital sensitivity of risk when franchise value changes.

$Z$ is a vector of macroeconomic factors common to the decisions of all banks. In $Z$, we include the industrial production index (indpro), the stock price index (stock), the interbank money market rate ( call) and the spread between the lending and deposit rates (spread). The industrial production index and the stock price index capture their influence on the distribution function for the rate of return on loans. The call rate and the spread between lending and deposit rates are included because the call rate is regarded as reflecting the opportunity cost of credit supply and the spread as representing the profitability of banks.

To take into account the endogeneity of capital and the serial correlation of risk, we estimate the dynamic panel model with a GMM estimator (Arellano and Bond, 1991). This is accomplished by using specified lags for both dependent and independent variables as instruments. We eliminate fixedeffects by first differencing the equation and require that all instruments, except for the macroeconomic variables in $Z$, be dated $t-2$ or earlier. We assume that $Z$ is strictly exogenous, while other regressors are allowed to be contemporaneously correlated with risk.

The validity of the above estimation is checked with two diagnostic tests. $\mathrm{AR}(1)$ and $\mathrm{AR}(2)$ test for first and second order residual serial errors. The lack of second order serial correlation validates the use of the instruments at $t-2$. Next, the Sargan test is used to determine whether over-identifying instruments are independent of the estimated errors. Non-rejection of the null hypothesis of independence validates the instruments we use.

In the Table 3, we present the summary statistics of a sample of 35 private banks between 1990 and 2000. The choice of the sample is the same as examined in Section 2. The table reports the descriptive statistics 
including the mean, the standard deviation, the minimum, the maximum, the median, and the first and third quartile values.

The mean and median sizes of our sample banks measured by real estate loan ratios (Risk) are $5.63 \%$ and $3.31 \%$, respectively, suggesting that the distribution of this variable is skewed to the right. As a matter of fact, approximately one-fourth of our sampled banks invest in the real estate sector more than $10 \%$ of their risk-adjusted assets. The ratio of subordinated debt to risk-adjusted assets (Subdebt) also displays a skewed distribution. The mean and median of the subordinated debt ratio are $1.65 \%$ and $1.39 \%$, respectively.

Table 4 reports the estimation results. Franchise value (fran) does not seem to be a determinant of risk in the first equation if we assume a linear specification of estimation. In the second equation, however, the coefficient of the interaction term between bank capital (cap) and franchise value (fran) is significant at the $10 \%$ level, suggesting that the risk-capital relationship is indeed nonlinear and depends on the level of franchise value. From the negative coefficient of bank capital (cap) and the positive coefficient of the interaction term, the sensitivity of risk with respect to bank capital is found to be positive when franchise value (Tobin's $q$ ) is above 1.90, but becomes negative when franchise value falls below this threshold. This result supports our hypothesis that franchise value matters in the riskcapital relationship. The critical value of franchise value lies between the 75th percentile (1.56) and the maximum (3.21), suggesting that many banks respond to a decline in capital by taking greater risk instead of taking lower risk.

The coefficients represent that a one standard deviation decline in the ratio of capital to risk-adjusted assets increases the real estate loan ratio by $0.11 \%$ (absolute change in the percentages, hereafter) for the banks with franchise values at the median. This effect is even stronger for banks with lower franchise values. The banks with franchise values at the 25 th percentile increase their portfolio of real estate assets by $0.15 \%$. In the steady state, where the lagged risk on the right hand side equals the current risk on the left hand side, the long-run effect on risk of a one standard deviation decline of capital is $0.40 \%$ for the banks with franchise values at the median and $0.55 \%$ for the banks with franchise values at the 25 th percentile. Note that the overall proportion of real estate loans increased by $2 \%$, from $11 \%$ in 1990 to $13 \%$ in 1999, as can be seen in Figure 2. The risk-shifting incentives due to low capital and low franchise values play a significant role in the portfolio risk decisions of Japanese banks. 


\subsection{Effect on Risk of Policy Shocks Affecting Capital}

\subsubsection{Capital Adequacy Requirements}

Next we examine whether capital-constrained banks take more risks than unconstrained banks (Proposition 2). As discussed in Section 2, we use the subordinated debt ratio as a proxy for the extent of capital adequacy regulatory pressure since undercapitalized banks issued more subordinated debts to meet the requirement.

The equation we estimate is:

$$
\begin{gathered}
\operatorname{risk}_{i, t}=\alpha_{1}+\beta_{1} \text { risk }_{i, t-1}+\beta_{2} \text { cap }_{i, t}+\beta_{3} \text { subdebt }_{i, t}+B Z_{t}+\varepsilon_{i, t} \\
\varepsilon_{i, t}=\mu_{i}+\nu_{i, t},
\end{gathered}
$$

where subdebt is the ratio of subordinated debt to risk-adjusted assets. We incorporate the capital-asset ratio (cap) as a control variable, in addition to macroeconomic variables $(Z)$, because it is a key determinant of bank risk (risk) and significantly related to the subordinated debt ratio (subdebt). If the capital requirement encourages, instead of discourages, risk-taking by banks, we would expect a positive relation between the subordinated debt ratio and the risk measure.

The results from the first regression of Table 5 indicate that the coefficient of the subordinated debt ratio is positive and significant at the $5 \%$ level. The coefficient shows that a one standard deviation increase in subordinated debt represents an increase in the real estate loan ratio of $0.22 \%$ and the long-run effect is $0.82 \%$. This suggests that when the capital requirement was about to be binding, banks issued more subordinated debt to meet the requirement and invested more in the real estate sector than unconstrained banks did.

This perverse effect of capital requirements is worth noting as this Japanese experience lies in sharp contrast with the "credit crunch" observed in the U.S. banking industry. Peek and Rosengren (1994, 1996) explain that banks in New England in the early 1990s could not recapitalize because issuing stocks would have incurred substantial agency costs under asymmetric information. Accordingly, they had no alternative but to reduce their assets, especially loans to the real estate sector. Conversely, since Japanese banks issued subordinated debts with less difficulty, they increased their real estate loans and took greater risks. Neither a capital requirement as regulatory pressure nor subordinated debts worked properly to limit the risk-taking behavior of Japanese banks. 


\subsubsection{Government Capital Injections}

In March 1998 and March 1999, the government injected public funds into banks in order to help them raise their capital ratios. Among the 35 banks in our sample, 17 banks applied for capital injections in 1998 and 14 banks applied in 1999. Because weak banks did not want to draw attention to themselves by applying for more capital injections, most banks applied for the same amount (100 billion yen) in 1998. Contrary to the first injections, the amount varied by banks and reflected the conditions of individual banks for the second injections in 1999.

In the second regression of Table 5, we drop the subordinated debt ratio and replace it with the government capital injections as a share of riskadjusted assets (injection) due to their high correlation. The correlation between the two variables is 0.46 with a p-value of 0.001 . This suggests that government allocated more public funds to weakly capitalized banks with more subordinated debt issuance. The question we ask here is whether the capital injections by the government reduce the banks' holdings of risky assets (Proposition 3).

The estimated coefficient on capital injections is consistent with what we would expect, which is negative and significant at the $5 \%$ level. A one standard deviation increase in capital injections by the government implies a decrease in the real estate loan ratio by $0.23 \%$ and the long-run effect is $0.84 \%$. It follows from this that government capital injections led banks to reduce lending to the real estate sector.

Although the difference in the result from the capital adequacy requirement is striking, we need to be cautious in interpreting this regression result because the capital injections were accompanied by stringent conditions for the recipient banks from the government (e.g. submission of restructuring plans). Some commentators argued that the conditionality of the injections was more effective than the capital injections themselves in stopping banks' risk-taking. However, it is not an easy task to distinguish between the effect of capital injections and that of the accompanying conditions. We demonstrate here that the risk-reducing effect of capital injections can be explained by our forward-looking model with franchise values.

\section{Conclusion}

In this study, we have examined why Japanese banks increased their exposure to the real estate sector during the 1990s despite the downward trend of land prices. Using the real estate loan ratio as a new proxy for portfolio 
risk of banks, we find evidence to support the "gambling for resurrection" hypothesis: banks with low capital-to-asset ratios and low franchise values choose high-risk assets at the expense of the deposit insurance system. We also find that the capital-risk relationship changes from positive to negative as franchise value falls. Franchise value has significant bearings on banks' risk decisions.

Next we investigate whether a capital adequacy requirement and government capital injections were effective in limiting the risk-taking behavior of banks. We find, using the subordinated debt ratio as a proxy for the regulatory pressure of a capital requirement, that capital-constrained banks take greater risks. Since it is less difficult for undercapitalized banks to issue subordinated debts to meet the capital requirement, they could afford to lend more to the real estate sector. In contrast, government capital injections led banks to decrease risky loans at the margin.

It should be emphasized that neither a capital adequacy requirement as regulatory pressure nor subordinated debts as market discipline functioned to reduce banks' risk-taking. These empirical results have several policy implications.

Firstly, the capital adequacy requirement should be adjusted to risk levels by sector. Since the current BIS risk-adjusted capital standards put the same risk-weights on loans, this may lead to the capital requirement being ineffective.

Secondly, the role of subordinated debt in the context of a capital adequacy requirement has to be reconsidered. Most subordinated debts issued by banks were purchased by insurance companies and non-financial companies which have intimate relationships with the issuing banks. Both insurance companies and non-financial companies are major shareholders of the banks, while banks are also their major shareholders. Hence, there is no problem of asymmetric information between issuing banks and buyers of subordinated debts. This is one of the reasons why subordinated debts did not play the role of market discipline. The close relationship between banks and these affiliated firms helped the recapitalization of banks and mitigated the credit crunch. However, it consequently allowed banks to shift their loan portfolio toward the most risky industry, the real estate sector, and to eventually accumulate non-performing loans.

Thirdly, the financial authority should also take responsibility for the risk-taking behavior of banks. Indeed several measures were taken to avoid the credit crunch, but the financial authority did not pay enough attention to banks' risk-shifting incentives and the resultant bad loan problem. Regulatory forbearance of problem banks remains a significant issue in Japan. 
Acknowledgement I am indebted to an anonymous referee, Aaron Tornell, Carlos Vegh, Martin Schneider, Rossen Valkanov and seminar participants at UCLA and IMF for many helpful suggestions. I also thank Kaoru Hosono and Masaya Sakuragawa for sharing data from Japanese banks. All errors are mine. This work was supported by a MEXT grant for young scientists (B)(16730164). 


\section{References}

[1] Arellano, M., Bond, S., 1991. Some tests of specification for panel data: monte carlo evidence and an application to employment equations. Review of Economic Studies 58, 277-297.

[2] Blum, J., 1999. Do capital adequacy requirements reduce risks in banking? Journal of Banking and Finance 23, 755-771.

[3] Blum, J., 2002. Subordinated debt, market discipline, and bank's risk taking. Journal of Banking and Finance 26, 1427-1441.

[4] Dewatripont, M., Tirole, J., 1995. The prudential regulation of banks. The MIT Press, Cambridge, MA.

[5] Federal Deposit Insurance Corporation, 1997. An examination of the banking crises of the 1980s and early 1990s (volume 1), History of the Eighties - Lessons for the future.

[6] Furlong, F., Keeley, M., 1989. Capital regulation and bank risk-taking: a note. Journal of Banking and Finance 13, 883-891.

[7] Gan, J., 2001. What do capital requirements do when they are not binding? mimeo.

[8] Hancock, D., Wilcox, J., 1994. Bank capital and the credit crunch: The role of risk-weighted and unweighted capital regulations. Journal of the American Real Estate and Urban Economics Association 22, 1, 59-94.

[9] Haubrich, J., Wachtel, P., 1993. Capital requirements and shifts in commercial bank portfolios. Economic Review, Federal Reserve Bank of Cleveland 29, 3, 2-15.

[10] Herring, R., Wachter, S., 1999. Real estate booms and banking busts: an international perspective. Occasional Papers, no. 58, Group of Thirty, Washington.

[11] Horiuchi, A., Shimizu, K., 1998. The deterioration of bank balance sheets in Japan: risk-taking and recapitalization. Pacific-Basin Finance Journal 6, 1-26.

[12] Hoshi, T., 2001. What happened to Japanese banks? Monetary and Economic Studies February, 1-29. 
[13] Ito, T., Sasaki, Y., 1998. Impacts of the Basel capital standard on Japanese banks' behavior. NBER Working Paper 6730.

[14] Jacques, K., Nigro, P., 1997. Risk-based capital, portfolio risk, and bank capital: A simultaneous equation approach. Journal of Economics and Business 49, 533-547.

[15] Kaminsky, G., Reinhart, C., 1999. The twin crises: the causes of banking and balance-of-payments problems. American Economic Review 89, 473-500.

[16] Keeley, M., 1990. Deposit insurance, risk, and market power in banking. American Economic Review 80, 5, 1183-1200.

[17] Keeley, M., Furlong, F., 1990. A reexamination of mean-variance analysis of bank capital regulation. Journal of Banking and Finance 14, 6984 .

[18] Kim, D., Santomero, A., 1988. Risk in banking and capital regulation. Journal of Finance 43, 5, 1219-1233.

[19] Koehn M., Santomero, A., 1980. Regulation of bank capital and portfolio risk. Journal of Finance 35, 5, 1219-1233.

[20] Levonian, M., 2001. Subordinated debt and the quality of market discipline in banking. Mimeo.

[21] Marcus, A., 1984. Deregulation and bank financial policy. Journal of Banking and Finance 8, 557-565.

[22] Merton, R., 1977. An analytic derivation of the cost of deposit insurance and loan guarantees. Journal of Banking and Finance 1, 3-11.

[23] Milne, A., 2002. Bank capital regulation as an incentive mechanism: Implications for portfolio choice. Journal of Banking and Finance 26, $1-23$.

[24] Peek, J., Rosengren, E., 1994. Bank real estate lending and the New England capital crunch. Journal of the American Real Estate and Urban Economics Association 22, no.1, 33-58.

[25] Peek, J., Rosengren, E., 1996. Bank regulatory agreements and real estate lending. Real Estate Economics 24, 1, 55-73. 
[26] Shrieves, R., Dahl, D., 1992. The relationship between risk and capital in commercial banks. Journal of Banking and Finance 16, 439-457.

[27] Stiglitz, J., Weiss, A., 1981. Credit rationing in market with imperfect information. American Economic Review, 393-410.

[28] Ueda, K. 2000. Causes of Japan's banking problems in the 1990s. in Hoshi and Patric eds., Crisis and change in the Japanese financial system. Chapter 3. 
Table 1. Proportion of non-performing loans by industry

\begin{tabular}{lrrrr}
\hline & 1999 & \multicolumn{1}{c}{2000} & \multicolumn{1}{c}{2001} & \multicolumn{1}{c}{2002} \\
\hline Real estate & 27.11 & 27.83 & 30.43 & 34.98 \\
Construction & 6.73 & 13.18 & 9.66 & 11.00 \\
Financial institutions & 11.30 & 8.15 & 5.92 & 6.00 \\
Manufacturing & 8.34 & 5.19 & 8.24 & 9.12 \\
Services & 23.20 & 22.28 & 19.30 & 13.07 \\
Wholesale and retail & 13.90 & 15.75 & 16.19 & 16.55 \\
Individual and other industry & 9.43 & 7.61 & 10.26 & 9.26 \\
\hline \multicolumn{1}{c}{ Total (\%) } & 100.00 & 100.00 & 100.00 & 100.00 \\
\hline
\end{tabular}

An average of the proportion of non-performing loans by industry for 4 major city banks is presented. The sample consists of UFJ, MitsuiSumitomo Bank, Mizuho Bank, and Bank of Tokyo-Mitsubishi during March 1999-March 2002 (end of fiscal year). Data on non-performing loans are obtained from Tankan reports of individual banks. 
Table 2. Analysis of subordinated debt

\begin{tabular}{lll}
\hline subordinated debt & Tobit & $\begin{array}{c}\text { Random- } \\
\text { Tobit }\end{array}$ \\
\hline constant & $0.098^{* * *}$ & $0.078^{* * *}$ \\
equity capital & $(0.005)$ & $(0.004)$ \\
hidden capital gains & $-0.899^{* * * *}$ & $-0.572^{* * *}$ \\
& $(0.043)$ & $(0.034)$ \\
provisions for loan losses & $-0.616^{* * *}$ & $-0.777^{* * *}$ \\
& $-0.059)$ & $(0.040)$ \\
& $(0.400)$ & $-0.947^{* * *}$ \\
\hline no. of obs. & 347 & 347 \\
no. of groups & 35 & 35 \\
\hline
\end{tabular}

The results of Tobit and Random-Tobit estimates of the determinants of subordinated debt issuance are presented. The latent variable in the index function equals the ratio of subordinated debts to total risk-adjusted assets, if it takes a non-negative value. The independent variables in the function are bank equity capital, hidden capital gains and provisions for loan losses, each as a proportion of total risk-adjusted assets at time $t-1$. Year dummies are also included to control for time trends, but their coefficients are not reported. The sample consists of 35 private banks subject to the 8 percent BIS capital adequacy requirement as of March 1999. The sample period is between 1990 and 2000. 302 observations are uncensored, 45 observations censored. Figures in parentheses are standard errors. Significance of the coefficients at the $10 \%, 5 \%, 1 \%$ level are denoted by $*, * *, * * *$, respectively. 
Table 3. Summary statistics

\begin{tabular}{lccccccc}
\hline \multicolumn{1}{c}{ Variables } & Mean & Std.dev. & Min. & $Q 1$ & Median & $Q 3$ & Max. \\
\hline Panel A. Bank & characteristics & & & & & \\
Risk (\%) & 5.63 & 5.59 & 0.25 & 0.94 & 3.31 & 9.45 & 21.58 \\
Cap (\%) & 9.80 & 1.29 & 6.98 & 8.96 & 9.44 & 10.39 & 15.40 \\
Subdebt (\%) & 1.65 & 1.43 & 0.00 & 0.42 & 1.39 & 2.63 & 6.68 \\
Injection (\%) & 1.62 & 1.30 & 0.17 & 0.42 & 1.28 & 2.48 & 5.13 \\
Fran & 1.26 & 0.49 & 0.67 & 0.92 & 1.18 & 1.56 & 3.21 \\
\multicolumn{7}{l}{ Panel B. Macroeconomic variables } \\
Indpro & 113.8 & 4.8 & 107.6 & 109.1 & 112.7 & 117.8 & 124.3 \\
Stock & 20.1 & 4.3 & 15.4 & 16.5 & 19.1 & 21.4 & 30.0 \\
Call (\%) & 3.13 & 3.01 & 0.04 & 0.45 & 1.75 & 6.50 & 8.56 \\
Spread (\%) & 3.93 & 1.33 & 2.33 & 2.55 & 4.08 & 5.17 & 6.12 \\
\hline
\end{tabular}

Descriptive statistics are presented for a sample of 35 Japanese banks between 1990 and 2000. Panel A presents measures of bank characteristics: the real estate loans as a share of total loans outstanding (Risk), the ratio of capital to risk-adjusted assets $(\mathrm{Cap})$, the ratio of subordinated debt to risk-adjusted assets (Subdebt), the ratio of the government capital injections to the risk-adjusted assets (Injection) and the franchise value (Fran), measured by Tobin's average q (the ratio of total market value to book value of equity capital). The sample of Injection covers only capital injected banks. Panel B include the industrial production index (Indpro), Nikkei 225 stock price index (Stock, divided by 1000), the interbank money market rate $(\mathrm{Call})$ and the spread between the lending and deposit rates (Spread). Data on bank characteristics are obtained from banks' financial statements and Nikkei Financial Quest database. Data on macroeconomic variables are obtained from Nikkei Financial Quest database. 
Table 4. Effects of capital and franchise value on bank risk

\begin{tabular}{cll}
\hline risk & \multicolumn{2}{c}{$\begin{array}{c}\text { Estimated coefficient } \\
\text { (Standard error) } \\
\text { [P-value] }\end{array}$} \\
\hline const. & $\begin{array}{l}0.043^{* * *} \\
(0.015)\end{array}$ & $\begin{array}{l}0.049^{* * *} \\
(0.015)\end{array}$ \\
risk -1 & $\begin{array}{l}0.730^{* * *} \\
(0.027)\end{array}$ & $\begin{array}{l}0.721^{* * *} \\
(0.027)\end{array}$ \\
cap & $-0.122^{* *}$ & $-0.230^{* * *}$ \\
& $(0.049)$ & $(0.075)$ \\
fran & -0.001 & $-0.012^{* *}$ \\
& $(0.001)$ & $(0.006)$ \\
fran $\times$ cap & & $0.121^{*}$ \\
& & $(0.063)$ \\
indpro & -0.043 & -0.0003 \\
& $(0.150)$ & $(0.150)$ \\
stock & -0.190 & -0.192 \\
& $(0.198)$ & $(0.197)$ \\
call & 0.072 & 0.069 \\
& $(0.053)$ & $(0.053)$ \\
spread & $-0.193^{*}$ & -0.172 \\
& $(0.099)$ & $(0.099)$ \\
\hline AR $(1)$ & {$[0.000]$} & {$[0.000]$} \\
AR $(2)$ & {$[0.307]$} & {$[0.213]$} \\
Sargan & {$[0.482]$} & {$[0.539]$} \\
no. of obs. & 382 & 382 \\
no. of groups & 35 & 35 \\
\hline & &
\end{tabular}

The results of the dynamic panel model with a GMM estimator are presented. The dependent variable ( $r i s k)$ is the real estate loans as a share of total loans outstanding. The independent variables include the ratio of capital to risk-adjusted assets (cap), the franchise value (fran), measured by Tobin's average q (the ratio of total market value to book value of equity capital) and the interaction term between the capital-to-asset ratio and the franchise value. As control variables, macroeconomic factors common to all banks' decisions are also included. They are industrial production index (indpro), the stock price index (stock), the interbank money market rate (call) and the spread between the lending and deposit rates (spread). The sample consists of 35 private banks and the sample period is between 1990 
and 2000. Significance of the coefficients at the 10\%, 5\%, 1\% level are denoted by $*, * *, * * *$, respectively. $\mathrm{AR}(1)$ and $\mathrm{AR}(2)$ test the first and second order serial correlations of residuals. Lack of serial correlation found by the $\operatorname{AR}(2)$ test validates the use of $Y_{i, t-2}$ as an instrument. Sargan tests whether over-identifing instruments are independent of the estimated errors. Not rejecting the null hypothesis validates used instruments. 
Table 5. Effects on risk of policy shocks affecting capital

\begin{tabular}{|c|c|c|}
\hline risk & $\begin{array}{r}\text { Estimate } \\
\text { (Stand } \\
{[\mathrm{P}-}\end{array}$ & $\begin{array}{l}\text { coefficient } \\
\text { rd error) } \\
\text { alue? }\end{array}$ \\
\hline const. & $\begin{array}{l}0.043^{* * *} \\
(0.015)\end{array}$ & $\begin{array}{l}0.044^{* * *} \\
(0.015)\end{array}$ \\
\hline risk $_{-1}$ & $\begin{array}{l}0.734^{* * *} \\
(0.029)\end{array}$ & $\begin{array}{l}0.732^{* * *} \\
(0.027)\end{array}$ \\
\hline cap & $\begin{array}{l}-0.110^{* *} \\
(0.047)\end{array}$ & $\begin{array}{l}-0.058 \\
(0.051)\end{array}$ \\
\hline subdebt & $\begin{array}{l}0.152^{* *} \\
(0.065)\end{array}$ & \\
\hline injection & & $\begin{array}{l}-0.174^{* *} \\
(0.074)\end{array}$ \\
\hline indpro & $\begin{array}{l}-0.041 \\
(0.150)\end{array}$ & $\begin{array}{l}-0.090 \\
(0.150)\end{array}$ \\
\hline stock & $\begin{array}{l}-0.232 \\
(0.191)\end{array}$ & $\begin{array}{l}-0.255 \\
(0.186)\end{array}$ \\
\hline call & $\begin{array}{l}0.072 \\
(0.053)\end{array}$ & $\begin{array}{l}0.078 \\
(0.053)\end{array}$ \\
\hline spread & $\begin{array}{l}-0.197^{* *} \\
(0.100)\end{array}$ & $\begin{array}{l}-0.207^{* *} \\
(0.098)\end{array}$ \\
\hline $\operatorname{AR}(1)$ & {$[0.000]$} & {$[0.000]$} \\
\hline $\operatorname{AR}(2)$ & {$[0.151]$} & {$[0.273]$} \\
\hline Sargan & [0.529] & [0.348] \\
\hline no. of obs. & 382 & 382 \\
\hline no. of groups & 35 & 35 \\
\hline
\end{tabular}

The results of the dynamic panel model with a GMM estimator are presented. The dependent variable (risk) is the real estate loans as a share of total loans outstanding. The independent variables include the ratio of capital to risk-adjusted assets (cap), the ratio of subordinated debt to riskadjusted assets (subdebt) and the ratio of the government capital injections to the risk-adjusted assets (injection). As control variables, macroeconomic factors common to all banks' decisions are also included. They are industrial production index (indpro), the stock price index (stock), the interbank money market rate (call) and the spread between the lending and deposit rates (spread). The sample consists of 35 private banks and the sample period is between 1990 and 2000. Significance of the coefficients at the 10\%, 
$5 \%, 1 \%$ level are denoted by $*, * *, * * *$, respectively. $\mathrm{AR}(1)$ and $\mathrm{AR}(2)$ test the first and second order serial correlations of residuals. The figures in brackets are p-values. Lack of serial correlation found by the $\operatorname{AR}(2)$ test validates the use of $Y_{i, t-2}$ as an instrument. Sargan tests whether over-identifing instruments are independent of the estimated errors. Not rejecting the null hypothesis validates used instruments. 
Figure 1. Total loans and real estate loans (outstanding)

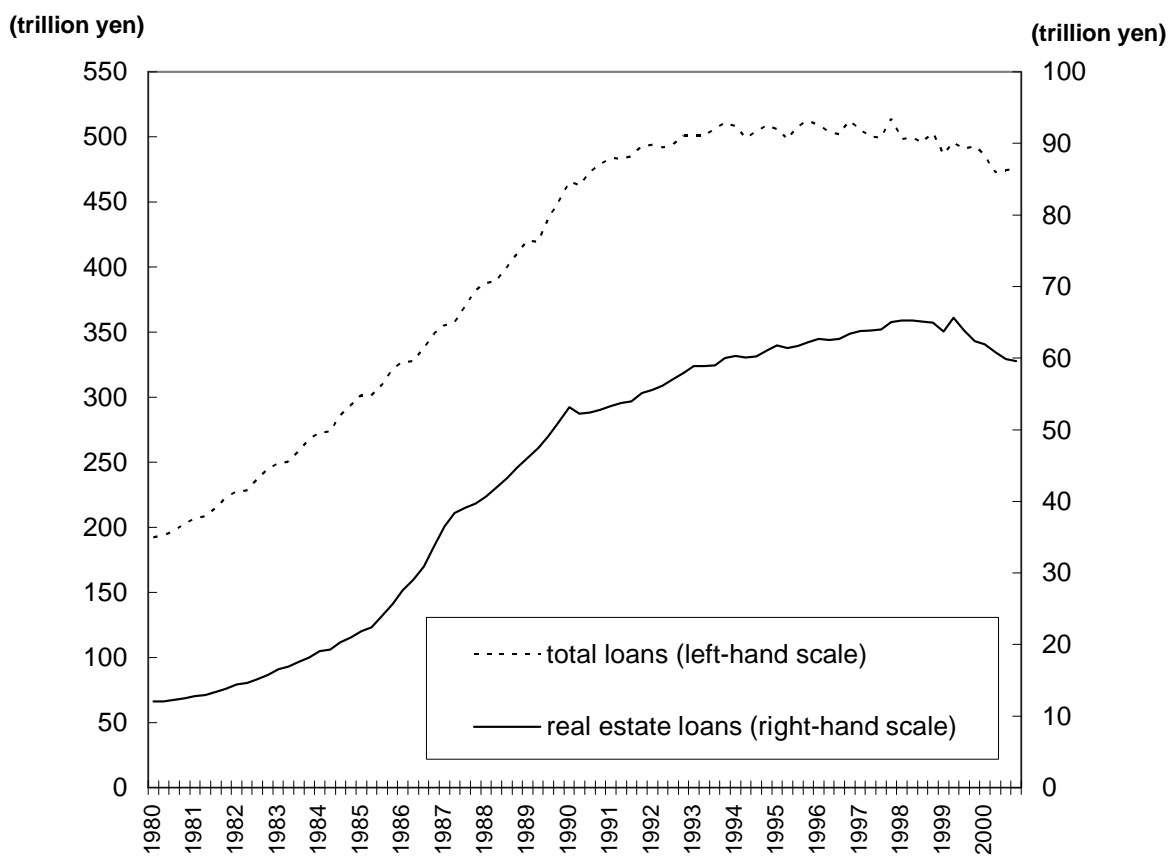

Figure 2. Proportion of real estate loans and manufacturing loans

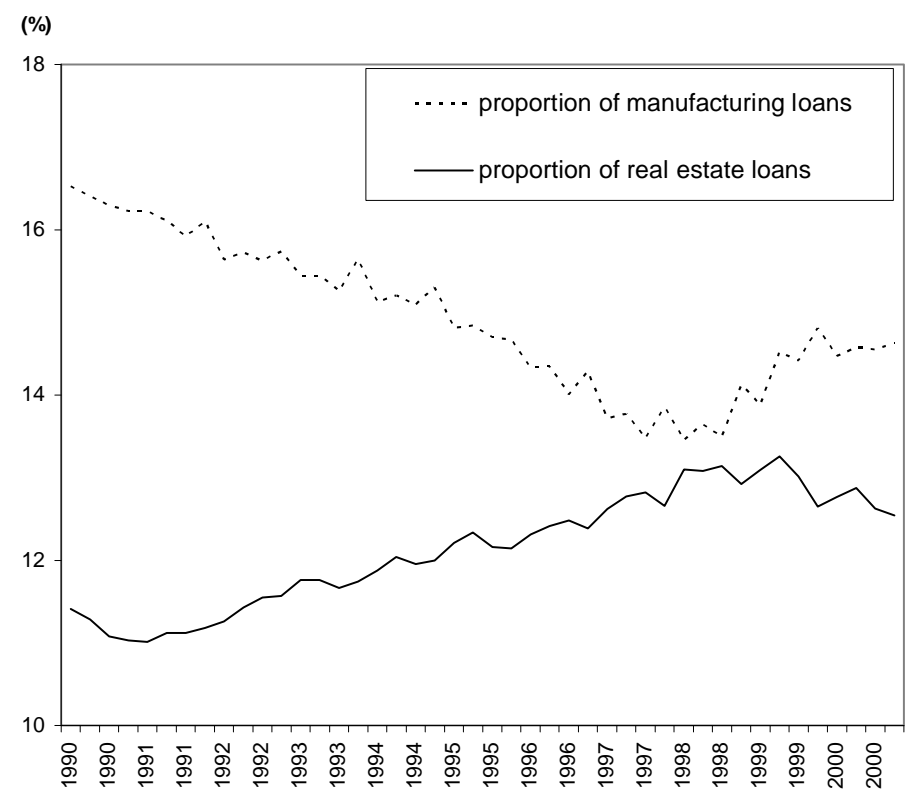


Figure 3. Land price index and stock price index

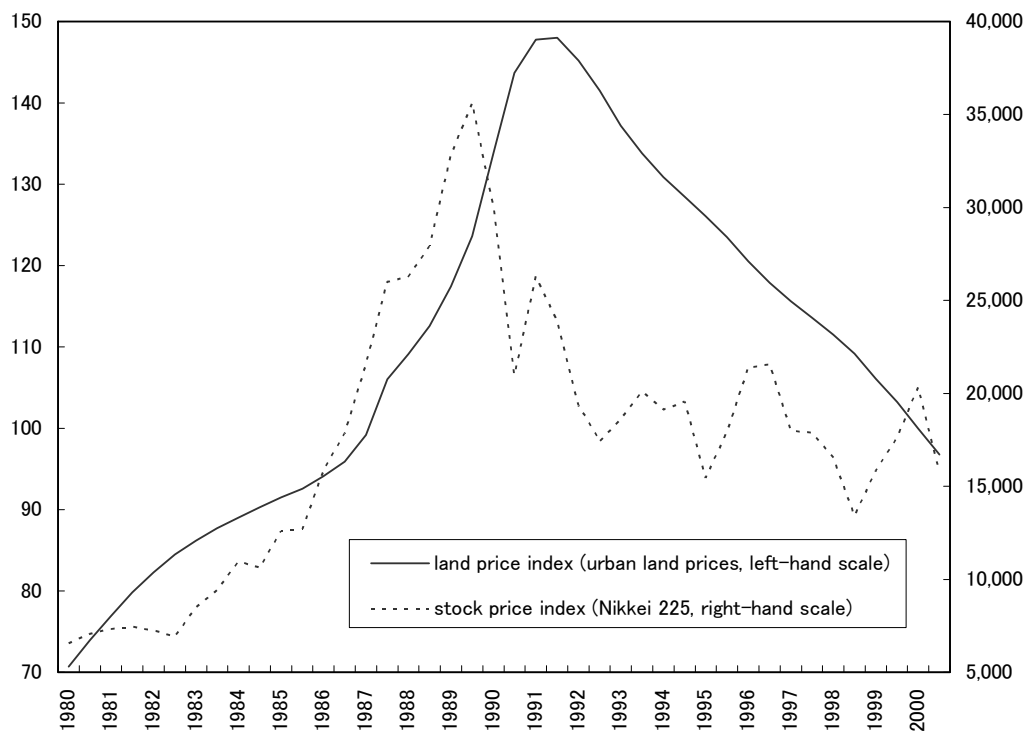

(\%)

Figure 4. Components of risk-weighted capital ratio (35 banks)

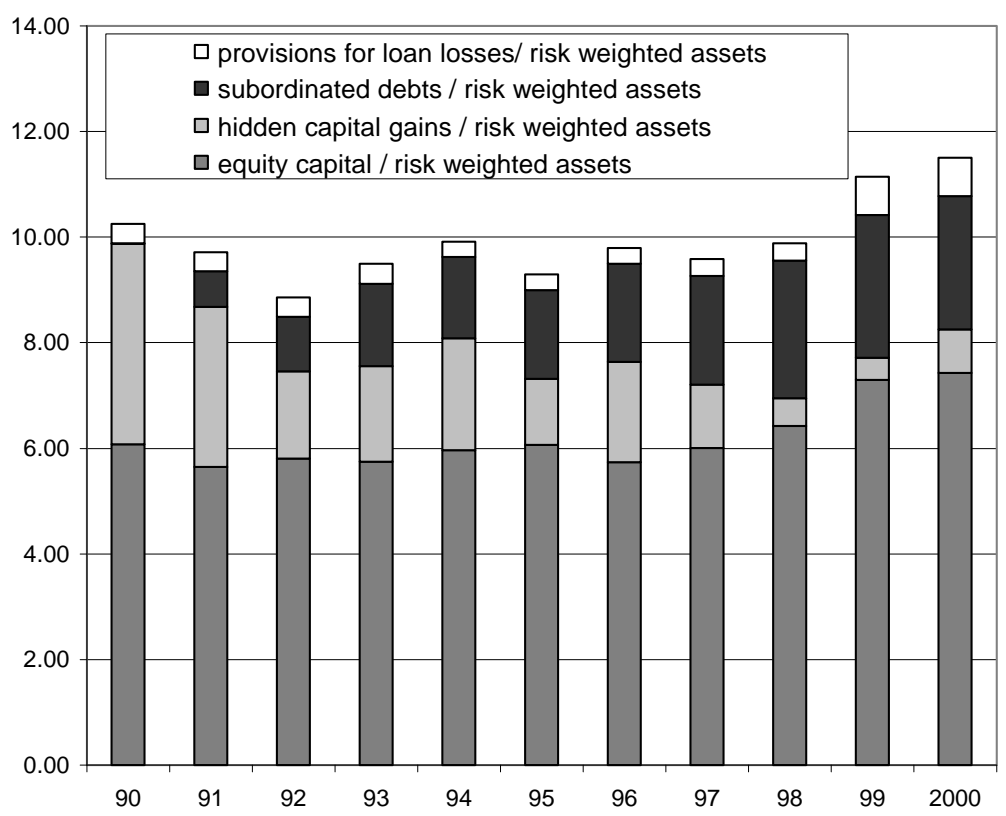

